\title{
Population dynamics of Thaumastocoris peregrinus in Eucalyptus plantations of South Africa
}

\author{
Ryan L. Nadel ${ }^{1 *}$, Michael J. Wingfield ${ }^{1}$, Mary C. Scholes ${ }^{2}$, Jeffrey R. Garnas ${ }^{3}$, Simon A. \\ Lawson $^{4}$ and Bernard Slippers ${ }^{1}$ \\ ${ }^{1}$ Department of Genetics, Forestry and Agricultural Biotechnology Institute, University of Pretoria, Pretoria \\ 0002, South Africa. \\ ${ }^{2}$ School of Animal, Plant and Environmental Sciences, University of the Witwatersrand, Private Bag 3, Wits \\ 2050, South Africa. \\ ${ }^{3}$ Department of Zoology and Entomology, Forestry and Agricultural Biotechnology Institute, University of \\ Pretoria, Pretoria 0002, South Africa. \\ ${ }^{4}$ Department of Agriculture, Fisheries and Forestry Queensland, and University of the Sunshine Coast, \\ Ecosciences Precinct, GPO Box 267, Brisbane, QLD 4001, Australia. \\ *Correspondence and present address: \\ Ryan L. Nadel \\ Institute for Commercial Forestry Research (ICFR), P.O. Box 100281, Scottsville, Pietermaritzburg, 3209 , \\ South Africa. \\ Tel.:+27 333862314 ; \\ Fax: +2733386 8905; \\ E-mail: Ryan.Nadel@icfr.ukzn.ac.za
}

\begin{abstract}
Thaumastocoris peregrinus is a sap sucking insect that infests non-native Eucalyptus plantations in Africa, New Zealand, South America and parts of Southern Europe, in addition to street trees in parts of its native range of Australia. In South Africa, pronounced fluctuations in the population densities have been observed. To characterise spatiotemporal variability in $T$. peregrinus abundance and the factors that might influence it, we monitored adult population densities at six sites in the main eucalypt growing regions of South Africa. At each site twenty yellow sticky traps were monitored weekly for 30 months, together with climatic data. We also characterised the influence of temperature on growth and survival experimentally, and used this to model how temperature may influence population dynamics.
\end{abstract}


T. peregrinus was present throughout the year at all sites, with annual site specific peaks in abundance. Peaks occurred during Autumn (February - April) for the Pretoria site, Summer (November - January) for the Zululand site and Spring (August - October) for the Tzaneen, Sabie and Piet Retief monitoring sites. Temperature (both experimental and field collected), humidity and rainfall were mostly weakly, or not at all, associated with population fluctuations. It is clear that a complex interaction of these and other factors (e.g. host quality) influence population fluctuations in an annual, site specific cycle. The results obtained not only provide insights into the biology of $T$. peregrinus, but will also be important for future planning of monitoring and control programs using semiochemicals, chemical insecticides or biological control agents.

\section{Keywords}

Critical thermal limits; Hemiptera; Phenology; Population monitoring; Thaumastocoridae

\section{Introduction}

Thaumastocoris peregrinus Carpintero and Dellapé (Hemiptera: Thaumastocoridae:

Thaumastocorinae) is a widely distributed eucalypt pest of Australasian origin (Carpintero and Dellapé 2006; Noack et al. 2011; Laudonia and Sasso 2012; Nadel and Noack 2012). Prior to reaching significant infestation levels on planted eucalypt trees in Sydney, Australia in 2002, very little research had been undertaken on any species of Thaumastocoris (or any of the Thaumastocoridae) (Noack and Coviella 2006; Noack 2009; Noack et al. 2011; Nadel and Noack 2012). T. peregrinus has become a major pest on various species of Eucalyptus across climatic regions in Southern Africa, South America, Southern Europe and New Zealand (Jacobs and Neser 2005; Carpintero and Dellapé 2006; Noack and Coviella 2006; Martínez and Bianchi 2010; Nadel et al. 2010; Wilcken et al. 2010; Laudonia and Sasso 2012; Nadel and Noack 2012; Sopow et al. 2012). Knowledge regarding factors that may influence the population dynamics of this pest in several climatic regions is, however, lacking (Martins and Zarbin 2013; Oumar and Mutanga 2013).

T. peregrinus is a small $(2-4.5 \mathrm{~mm})$, sap sucking, gregarious insect with both adults and nymphs feeding on the same leaf surface (Jacobs and Neser 2005; Noack and Rose 2007; Noack 2009). The life cycle lasts between 30 and 60 days including five nymphal instars (16 
- 20 days) and an adult phase ( \pm 14 - 42 days) facilitating several generations in a year (Noack and Rose 2007; Soliman et al. 2012). Lifetime fecundity is approximately 60 eggs which typically hatch within 6 days (at $17-22^{\circ} \mathrm{C}$ and $26^{\circ} \mathrm{C}$ ) (Noack and Rose 2007; Soliman et al. 2012). The short life cycle and high reproductive potential of T. peregrinus females thus allows for the rapid build-up of populations in areas where optimal conditions for its growth and survival occur.

T. peregrinus is a major pest on non-native eucalypts in South Africa. Initially discovered in the Pretoria region of Gauteng in 2003, it was only recognised as a serious pest of commercially grown eucalypts in 2005 when it initially infested plantations in the Gauteng, Limpopo, Mpumalanga and North West provinces (Jacobs and Neser 2005). The first symptoms of infestation were usually observed on the north to north eastern edge of a compartment (Nadel et al. 2010). T. peregrinus infestations result in reduced photosynthetic ability and in some cases death of severely infested trees (Nadel et al. 2010).

Bar-coding using COI mitochondrial DNA (mtDNA) revealed two separate introductions of T. peregrinus into South Africa, which very likely originated from urban centres in Australia (Nadel et al. 2010). The dominant mtDNA haplotype identified in the study by Nadel et al. (2010) was found to occur throughout South Africa, spanning all climatic regions where Eucalyptus is grown. Since its initial discovery in South Africa, T. peregrinus has spread throughout the country infesting numerous Eucalyptus species and commercially produced hybrid clones (Jacobs and Neser 2005; Nadel et al. 2010). The insect has also spread north in Africa, currently as far as Kenya (Nadel et al. 2010; Nadel and Noack 2012).

Initial observations and anecdotal reports have shown that $T$. peregrinus populations vary significantly during the year in South Africa, although population fluctuations in different regions and on different Eucalyptus species do not exhibit a strong or apparent synchronicity. The first aim of this study was to determine critical temperature thresholds and growth responses of $T$. peregrinus to temperature under controlled laboratory conditions. A second objective was to study the timing and phenology of population fluctuations in distinct regions of South Africa, to assess evidence for synchrony and to evaluate potential climatic drivers of population dynamics. 


\section{Materials and methods}

Growth and survival in relation to temperature for T. peregrinus

\section{Critical thermal limits}

Extreme temperatures can dramatically affect survival rates in insect populations and they can strongly influence population dynamics and persistence over time. Temperatures above and below thermal limits of an organism are defined as lethal temperatures, because they effectively result in death (Fry 1967; Block et al. 1990). An alternative method for measuring these thresholds, originally developed for experimentation on vertebrate poikilotherms, involves the measure of critical thermal activity limits, rather than lethal thresholds (Fry 1967). Critical thermal limits are defined as the maximum and minimum temperature just short of death, but where an organism loses its ability to move (Fry 1967). This method has been widely used in studies, including at least 6 invertebrate orders and 24 families, following the assumption that the identified thresholds closely track lethal minima and maxima (Kay and Whitford 1978; Mitchell et al. 1993; Klok and Chown 1997; AddoBediako et al. 2000).

To determine the critical thermal limits (Block et al. 1990) for T. peregrinus, 30 adults were placed into individual $1 \mathrm{ml}$ sealed tubes. The tubes were submerged in a water bath, the water temperature was either raised or lowered at a rate of $1^{\circ} \mathrm{C} . \mathrm{min}^{-1}$, from an initial water temperature of $15^{\circ} \mathrm{C}$. All tubes were removed and inverted every minute and the ability of the $T$. peregrinus adults to right themselves was assessed. The critical thermal limits $\left(\mathrm{CT}_{\max }\right.$ and $\mathrm{CT}_{\min }$ ) for each $T$. peregrinus adult was defined as the maximum and minimum temperature at which the adult could no longer right itself.

\section{Egg developmental rate}

To determine the effect of temperature on the rate of T. peregrinus egg development, eggs of known age were required. More than a hundred T. peregrinus adults were collected in Pretoria and placed in a sealed container to which paper towelling had been added. Forty eggs were removed from the paper towelling within two hours after the adult insects had been 
collected. Five eggs per treatment were placed onto moist filter paper and sealed in a Petri dish. Petri dishes were placed into one of eight incubators maintained at a constant temperature ranging from $0{ }^{\circ} \mathrm{C}$ to $35^{\circ} \mathrm{C}$ at five degree intervals and were monitored every 12 hours to record the number of hatched eggs. To determine the temperature at which egg development ceased (developmental zero), we examined the straight line linear relationship between rearing temperature and days to hatch (Campbell et al. 1974). The developmental zero of the eggs was estimated as being the point where the regression line intersected the temperature axis. To determine the accuracy of the developmental zero estimate and optimum developmental rate, eggs maintained $5{ }^{\circ} \mathrm{C}$ below the developmental temperature were monitored for thirty days to record any sign of hatching. They were later placed at the optimum developmental temperature to determine percent mortality and whether living eggs would develop normally.

Population modelling

DYMEX TM V3 (Maywald et al. 2007), a commercially available insect phenology modelling computer programme based on insect critical thresholds and developmental rates as a function of temperature and weather data was used. We used DYMEX to develop a population model for T. peregrinus based on our laboratory-determined adult threshold temperatures (this study). The DYMEX model developed for this research used threshold temperatures reported in this study for both adult and egg development, in addition to using data from Noack and Rose (2007) to calculate the developmental rate of the five nymphal life stages of T. peregrinus. Modelling was undertaken using daily temperature and rainfall data from the Pretoria site only, because data from this site was the most complete.

Population monitoring

To determine an optimal sample protocol for monitoring T. peregrinus populations, a pilot trial was initiated to determine the optimum position of trap placement and the best colour traps to capture adults (data not shown). Yellow sticky board traps placed at mid-canopy were found to be most effective in capturing $T$. peregrinus adults, confirmed by results from similar studies (Martínez et al. 2010). Six sites ranging in elevation from 47-1340 meters above sea level (m.a.s.l.) were placed in a stratified design across the main eucalypt growing areas of South Africa (Fig. 1and Table 1) and monitored between February 2007 and July 
Table 1: Site characteristics for six T. peregrinus monitoring sites in South Africa

\begin{tabular}{lcccccc}
\hline & & \multicolumn{2}{c}{ Monitoring site } \\
Site characteristics & Piet Retief & Pretoria & Sabie & Tzaneen, Site 1 & Tzaneen, Site 2 & Zululand \\
\hline Elevation (m a.s.I.) & 1219 & 1340 & 1280 & 1276 & 870 & 47 \\
Mean annual rainfall $(\mathrm{mm})$ & 841 & 711 & 1142 & 1253 & 1235 & 917 \\
Mean maximum temperature $\left({ }^{\circ} \mathrm{C}\right)$ & 23.2 & 24.9 & 22.1 & 23.6 & 25.5 & 27.1 \\
Mean minimum temperature $\left({ }^{\circ} \mathrm{C}\right)$ & 10.1 & 11 & 10.8 & 13 & 12.5 & 16.6 \\
Eucalyptus spp. & E. macarthurii & E. camaldulensis & E. grandis & E. grandis & E. grandis $\mathrm{x}$ Ealdulensis E. camaldulensis \\
\hline
\end{tabular}




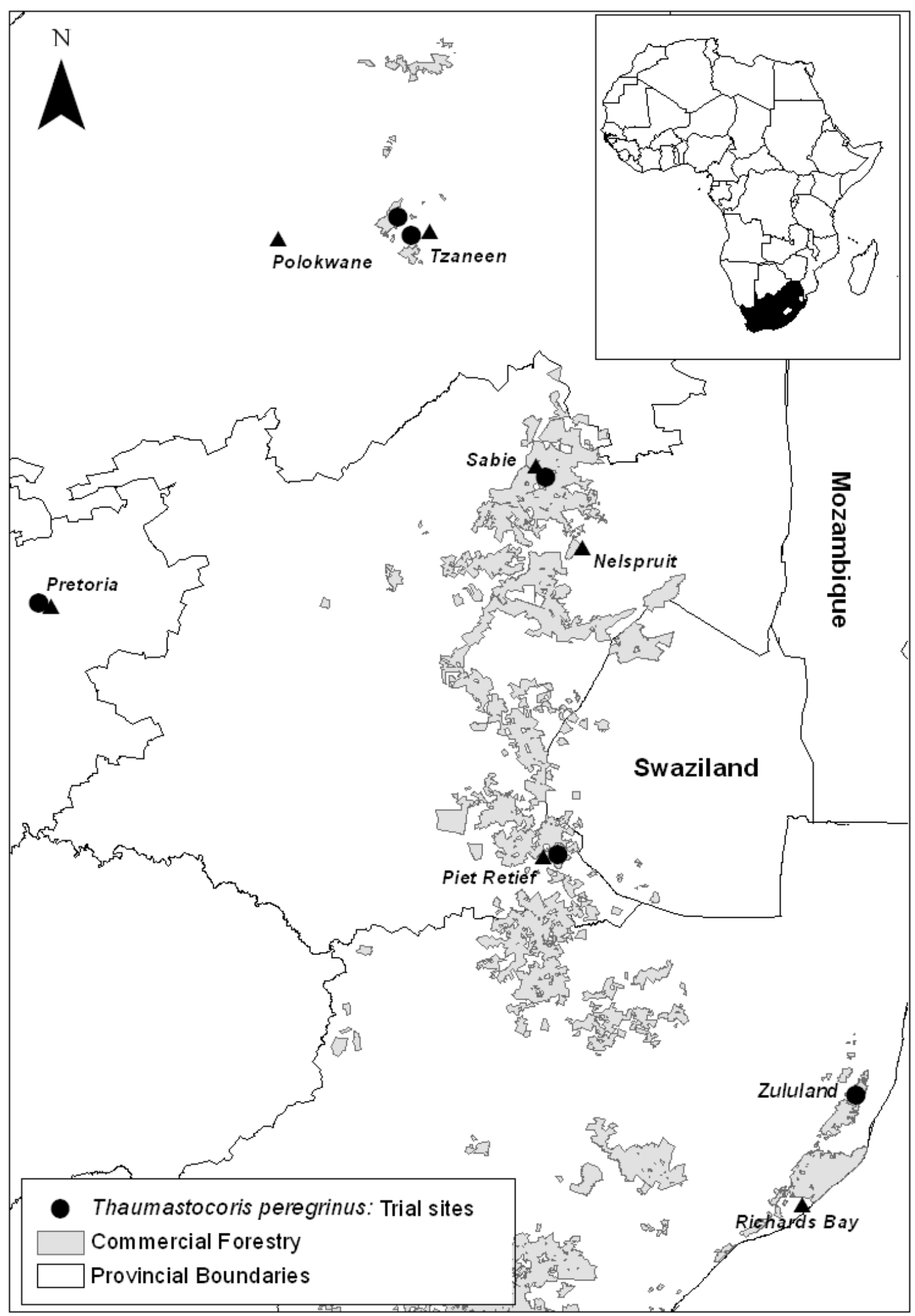

Fig. 1: Map of South Africa showing placement of T. peregrinus monitoring sites within Pretoria and the major commercial Eucalyptus growing regions of Tzaneen, Sabie, Piet Retief and Zululand. 
2009. The trial was established in collaboration with several commercial forestry companies participating in the Tree Protection Co-operative Programme (TPCP) (www.fabinet.up.ac.za/tpcp). The trapping sites included one in the Gauteng province (Pretoria), one in the KwaZulu-Natal province (Zululand), two sites in the Limpopo province (Tzaneen) and two sites in the Mpumalanga province (Sabie and Piet Retief) (Fig. 1and Table 1).

At each of the six monitoring sites, we placed 20 plastic yellow board sticky traps $(13 \mathrm{~cm} \times 8$ cm each; Insect Science (Pty) Ltd., Tzaneen, South Africa) on randomly-selected trees at a height of 3 meters, stratified by distance to the northern edge. For each site, 10 traps were placed at the north-facing compartment edge, where initial infestation symptoms are usually first noticed (unpublished observation) and 10 traps inside the compartment $>10 \mathrm{~m}$ from any edge. Compartments had Eucalyptus trees of similar size and age ( $\sim \mathrm{m}$ tall and 2-3 years old) across monitoring sites (Table 1).

We monitored temperature and humidity every two hours using DS1923 - F5 Thermochron $i$ Button ${ }^{\circledR}$ (Dallas Semiconductor/ Maxim, Dallas, TX, USA) data loggers placed in the middle of the canopy $(\sim 3 \mathrm{~m})$, suspended from a tree located at the centre of each monitoring site. Data loggers and traps were exchanged weekly. Traps were returned to the laboratory and total numbers of $T$. peregrinus adults were counted separately for each trap. Rainfall data were provided by the South African Weather Service from weather stations closest to the individual monitoring sites and aggregated to fortnightly averages. Insect abundance per trap and $i$ Button data (temperature and relative humidity) were likewise averaged fortnightly. Data exploration and visualization (specifically Fig. 4) was performed in R (R Core Team 2012).

\section{Results}

\section{Critical thermal limits}

T. peregrinus adults were not able to right themselves at temperatures between 32 and $45{ }^{\circ} \mathrm{C}$ and between 1 and $6{ }^{\circ} \mathrm{C}$. The mean $\mathrm{CT}_{\max }$ for T. peregrinus adults was $38.6 \pm 4.7{ }^{\circ} \mathrm{C}(n=30)$ and a $\mathrm{CT}_{\min }$ with a mean value of $3.8 \pm 1.9^{\circ} \mathrm{C}(n=30)$. Individual adults that were exposed 
to their critical thermal limits were subsequently able to recover normal movement when placed at temperatures ranging between 7 and $31^{\circ} \mathrm{C}$.

\section{Egg developmental rate}

T. peregrinus egg development was highest at a constant temperature of $30{ }^{\circ} \mathrm{C}$ ( 3 days with $15 \%$ mortality) and lowest (15 days) at a constant temperature of $15{ }^{\circ} \mathrm{C}$. No egg development occurred at $0,5,10$ and $35^{\circ} \mathrm{C}$ (Fig. 2) and these data were excluded from the linear regression analysis, as undertaken by Campbell et al(1974). The developmental zero of the eggs was calculated at $12.2{ }^{\circ} \mathrm{C}$ using the regression equation $\mathrm{y}=0.0178 \mathrm{x}-0.2178, R^{2}=$ $0.9731, p=0.0135$.

\section{DYMEX model}

The DYMEX simulated population dynamics of $T$. peregrinus predicted adult populations as peaking from October through to April at the Pretoria site and decreasing between the months May to July, with the opposite relationship occurring for the egg numbers at the site (Fig. 3). Predicted nymph numbers remained relatively constant throughout the duration of the simulated model (Fig. 3). Compared to the actual adult population data obtained for this site (Fig. 4), discrepancies were revealed in the extent and timing of population build-ups and declines between the simulated and actual populations. At the Pretoria site, the adult population increased from December - January, peaking in March- April and decreasing during May (Fig. 4), whereas the deterministic model populations had relatively constant population levels during the same time period.

\section{Monitoring trial}

The monitoring trial revealed unique patterns of $T$. peregrinus population growth and decline for each of the populations monitored (Fig. 1 and 4). Population abundance was strongly seasonal with a single peak per year at all sites. Trap catches varied dramatically between sampling time points, ranging from zero individuals to a maximum of approximately 60 individuals per trap at peak abundance at the Pretoria site. Despite long periods of low abundance, adults were present year round at all sites. Seasonality was consistent across the two years of sampling within sites (and between the two Tzaneen sites) but was highly divergent across sites. Populations peaked in Pretoria in Autumn (February-April; Fig. 4), 


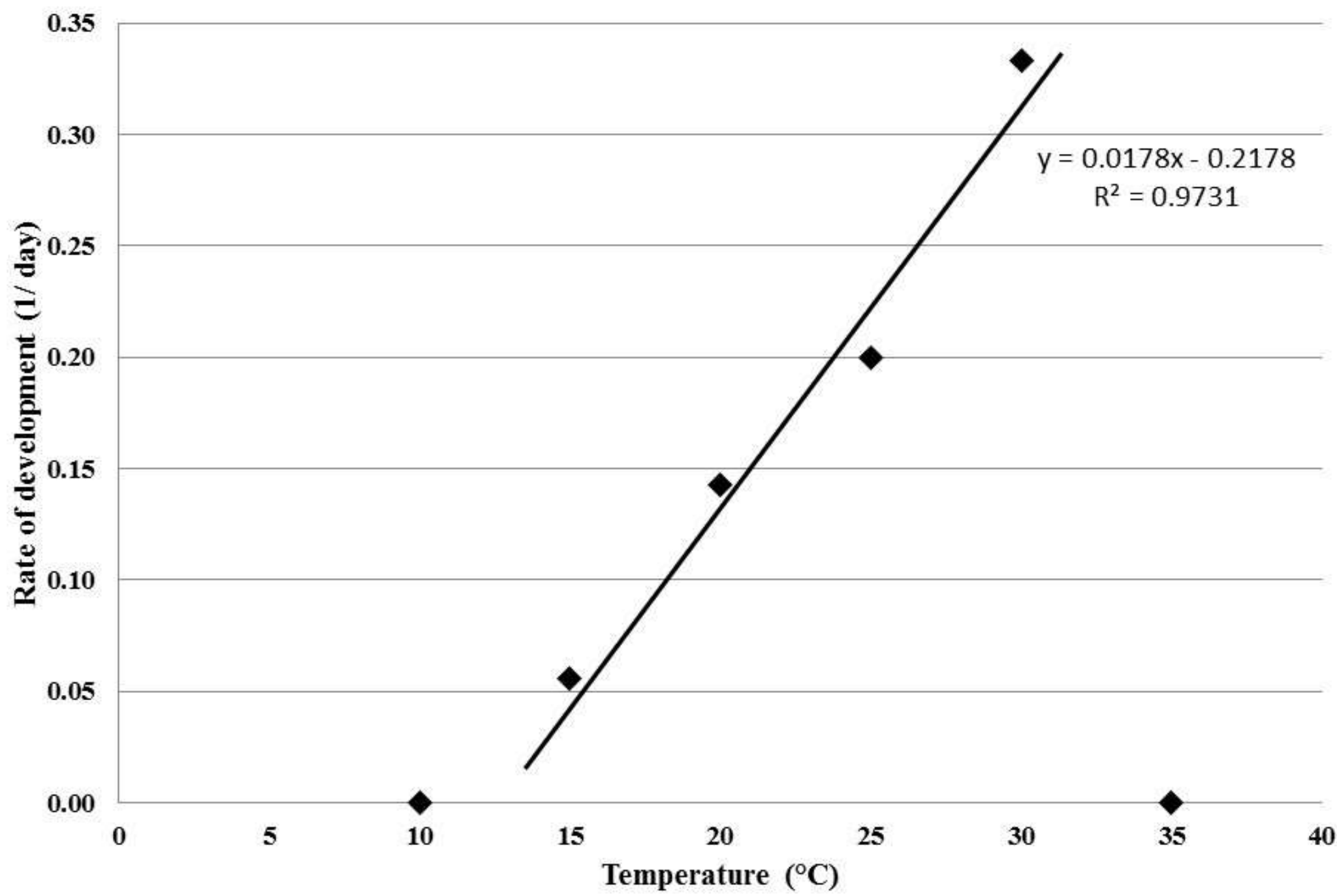

Fig. 2: The relationship between T. peregrinus egg development and temperature to determine the developmental rate equation $(y=0.0178 x-0.2178, R 2=0.973$, $p=0.01)$ from hatching eggs. 


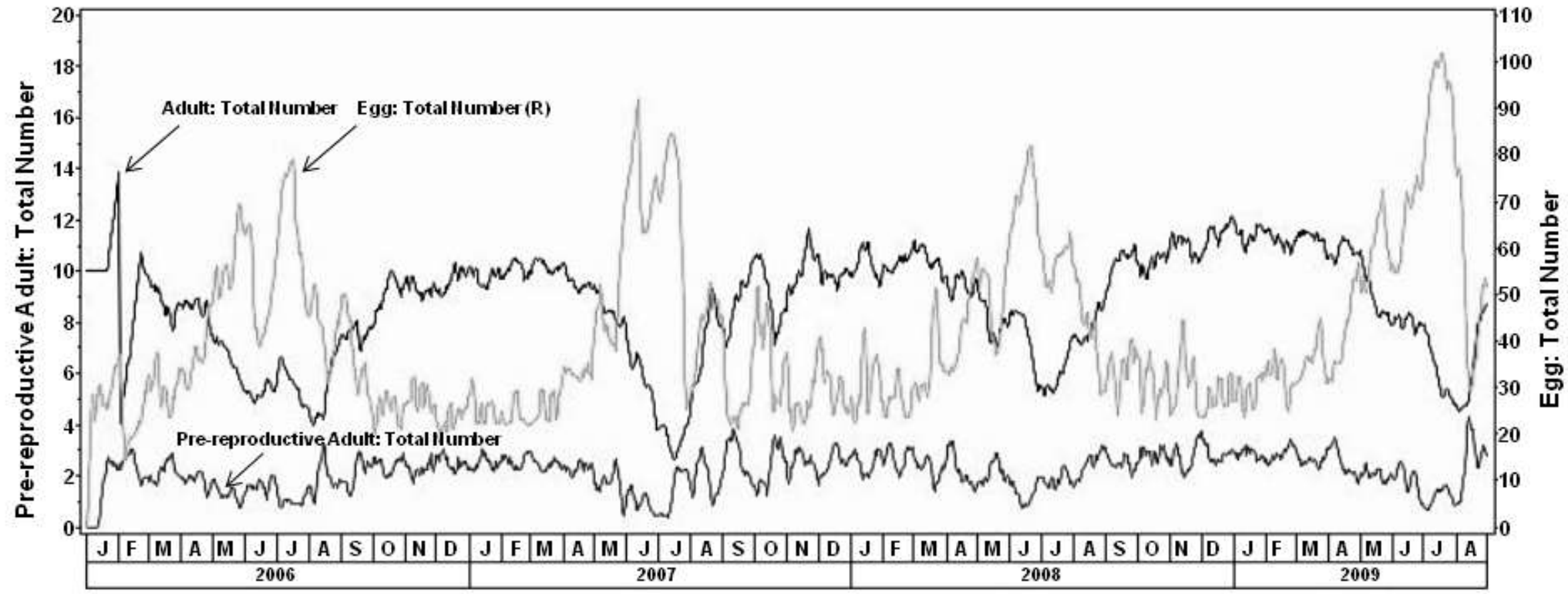

Fig. 3: An output of a DYMEX model simulation, predicting the population dynamics of the various life stages of T. peregrinus at the Pretoria monitoring over time. 
slightly earlier than at the warmer Zululand site (late Summer, January-March). The three northern most sites (Sabie and Tzaneen sites $1 \& 2$ ) peaked in spring (August-October) whereas Piet Retief had only one moderate peak in the Spring of 2007. Surprisingly, there was little evidence of a consistent pattern with temperature or relative humidity between sites based on climate records (Fig. 4).

Rainfall data for the Pretoria monitoring site (the only site to have a weather station in reasonably close proximity) revealed that rainfall at this site peaked in January, when adult population levels were still relatively low (Fig. 5). Adult population levels were found to be highest during the 2007/2008 season (year with the higher rainfall) compared to 2008/ 2009 season (Fig. 5).

\section{Discussion}

Monitoring T. peregrinus populations for 30 months across the main Eucalyptus growing regions of South Africa revealed a regular pattern of population build-up and decline. The fluctuations in populations at each monitoring site were remarkably consistent between years or seasons, but were unique for the different regions. Contrary to expectation, there were no consistent correlations between the presence of $T$. peregrinus and temperature, relative humidity, or rainfall across the sites. The relative synchronicity among sites in broadly similar regions suggests that these patterns cannot simply be random and the scale of apparent co-variation would seem to indicate a driver acting at a broad spatial scale, such as weather (Moran 1953). Liebhold et al. (2012) recently reviewed the direct impact of weather on survival and reproduction (termed the "Moran effect"(Moran 1953)), reviewing dispersal, regional stochasticity and trophic interactions as factors affecting spatial synchronicity (Liebhold et al. 2012). One plausible hypothesis for this study is that weather and trophic interaction effects on tree phenology (e.g. leaf flush and senescence) drive T. peregrinus seasonality more strongly than a direct effect of temperature. It has been shown that mated $T$. peregrinus females demonstrated a preference to volatile organic compounds emitted by undamaged Eucalyptus benthamii plants compared to those damaged by T. peregrinus (Martins and Zarbin 2013). Thus, the combined effect of climate factors on the actual plant growth of undamaged trees may indirectly regulate the population dynamics of $T$. peregrinus, rather than a direct effect per se. Such an indirect effect might then limit the utility of 

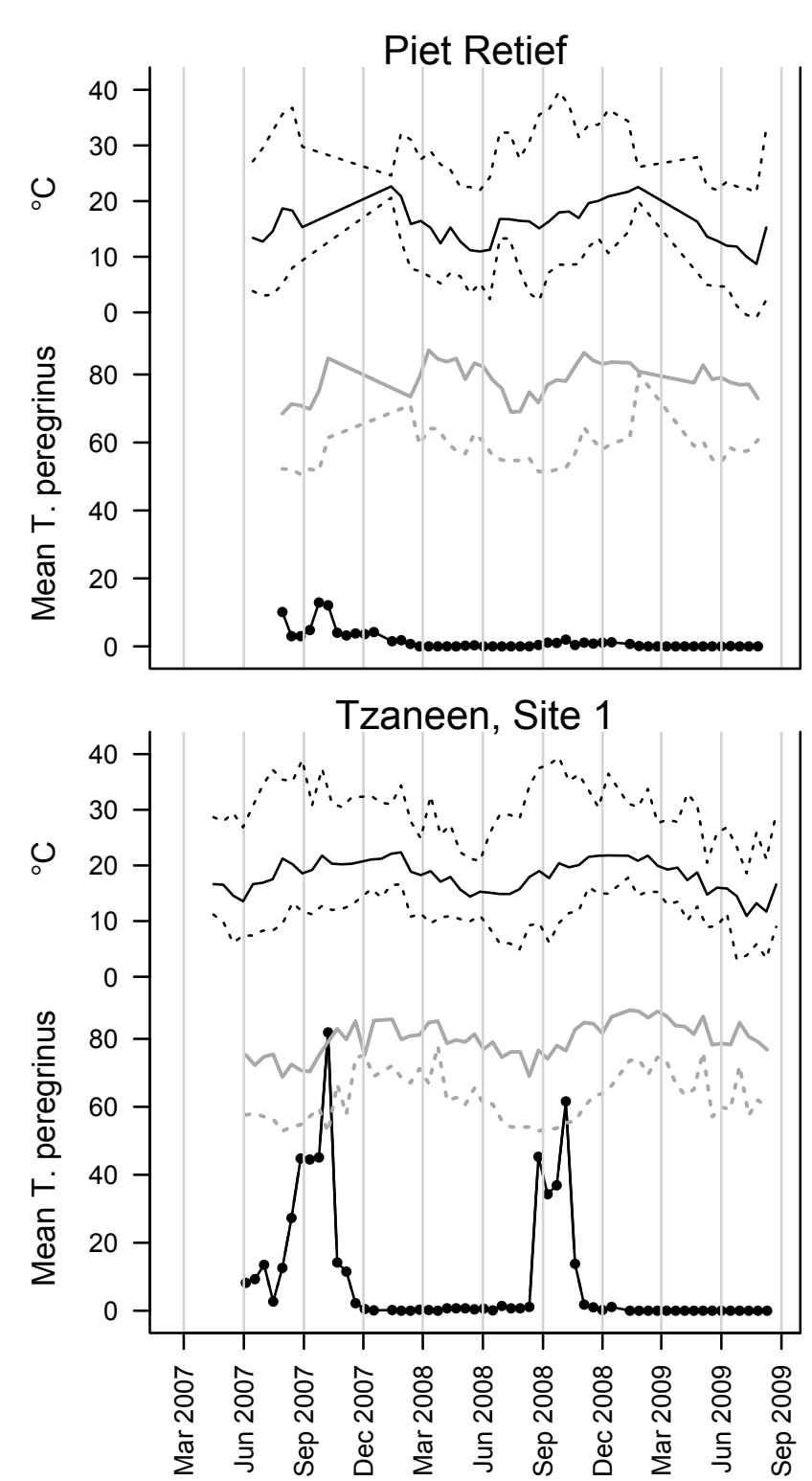

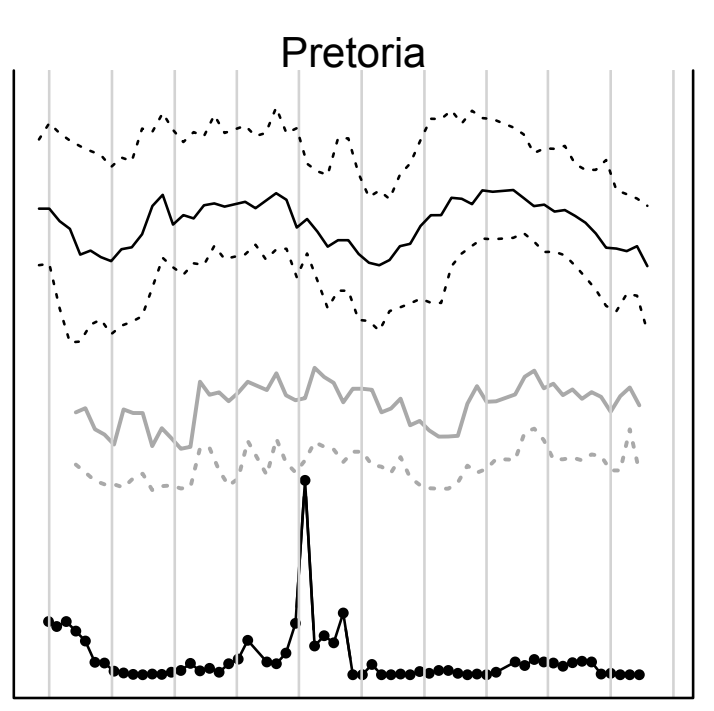

Tzaneen, Site 2

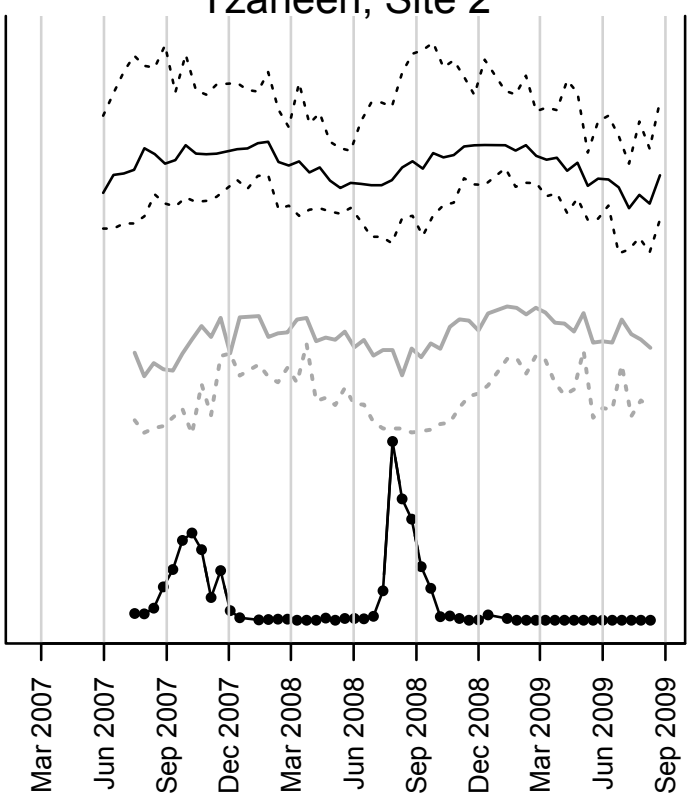

Sabie

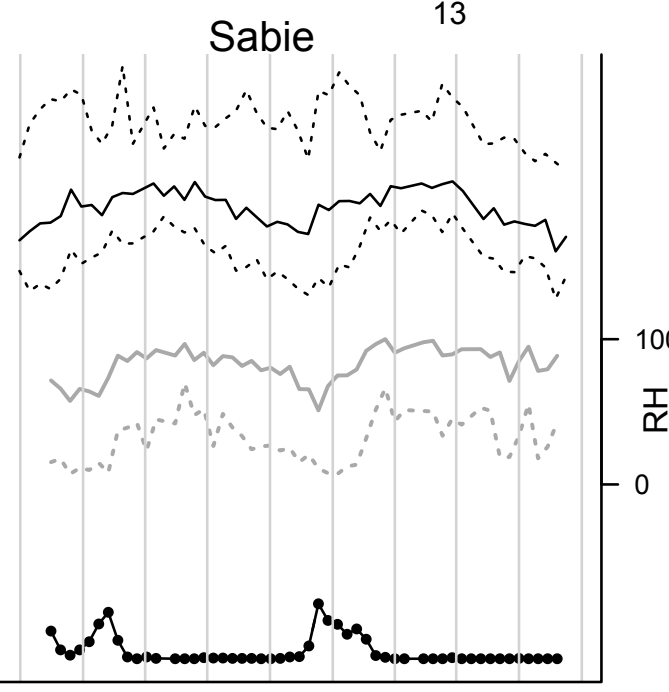

\section{Zululand}

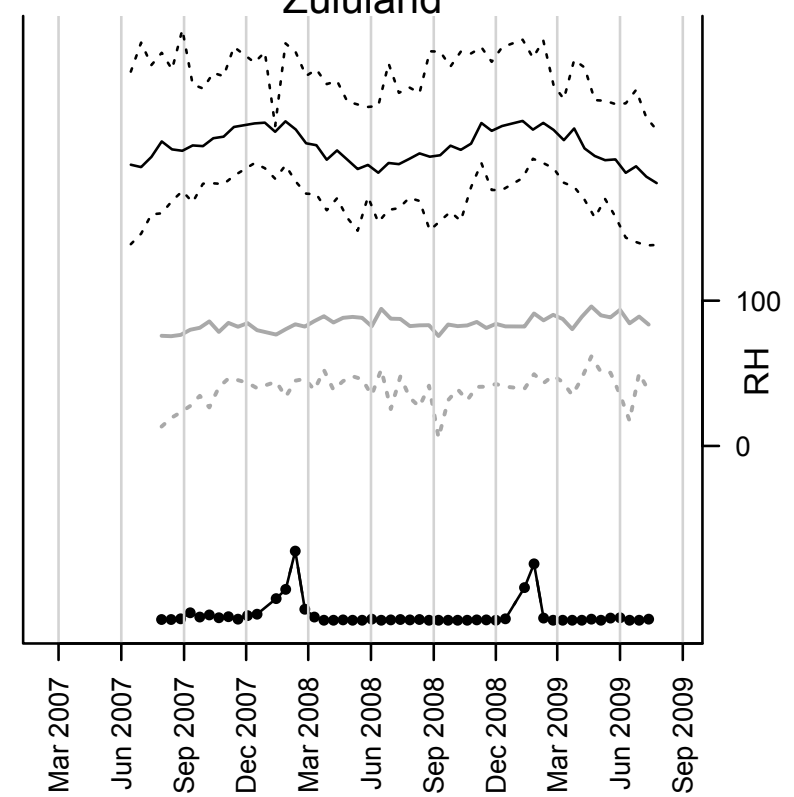

Fig. 4: Monthly temperature $\left({ }^{\circ} \mathrm{C}\right.$, left axes, top), relative humidity (RH, right axes) and the number of T. peregrinus adults collected per trap at for each of the monitoring sites Piet Retief, Pretoria, Sabie, Tzaneen site 1, Tzaneen site 2 and Zululand. 


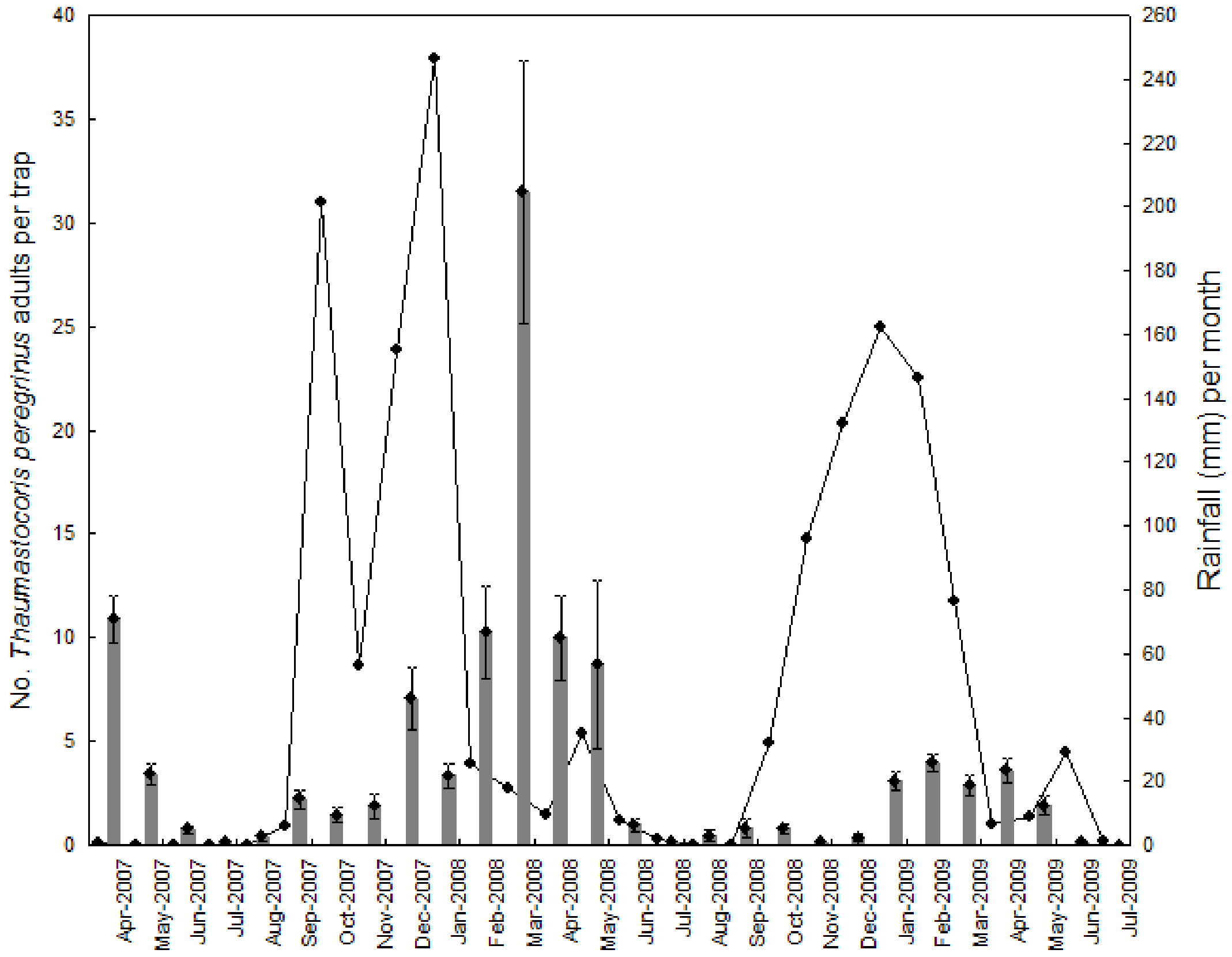

Fig. 5: Monthly rainfall (indicated by the line plot) and number of T. peregrinus adults collected per trap (indicated by the bar plot, vertical bars indicate $95 \%$ confidence intervals) at the Pretoria monitoring site. 
evaluating the direct effects of weather (climatic factors), especially using relatively short time series. Our data were not sufficient to test for such indirect effects, but this may be a fruitful avenue for future research.

The phenological model for T. peregrinus employing laboratory-derived temperature parameters was roughly plausible for the Pretoria site on which it was based. Comparisons of actual adult $T$. peregrinus monitoring data with that of simulation data revealed faster population build-ups and longer periods of high population levels compared to that of actual populations. The peaks from the model data also did not correlate with the actual data in Pretoria, where the most weather data were available. Further refinement of the model using more accurate nymphal development thresholds and incorporating mortality factors may improve matching with field data. Important factors for future study and potential input to the model include the effect of temperature on adult fecundity, temperature thresholds for each nymphal life stage, and bottom-up host effects, amongst others (Stiling 1988; Umbanhowar and Hastings 2002; Abbott and Dwyer 2007; Soliman et al. 2012).

T. peregrinus does not appear to undergo any diapause period and was active during all seasons at all monitoring sites, although sometimes in very low numbers. Diapause periods have likewise not been reported for any of the Thaumastocorinae. While T. peregrinus was present at all sites throughout the year, there were consistent annual seasonal peaks in the numbers of individuals, albeit to different total numbers caught. The consistent and repetitive annual fluctuations of populations at each monitoring site further suggest a strong local environmental effect on the population dynamics of this pest. Whether these influences are direct or indirect is, however, not clear. The consistent pattern of population build-ups and decline also suggests that the population dynamics might be predicted at a particular site for a particular Eucalyptus sp. using a model parameterised by data of previous years. Such models would facilitate more efficient monitoring and control including the potential use of semiochemicals (e.g. use of male aggregation pheromones) (González et al. 2012; Martins and Zarbin 2013), insecticides (Noack et al. 2009) and deployment and/or augmentative release of potential biological control agents such as Cleruchoides noackae Lin \& Huber (Lin et al. 2007; Mascarin et al. 2012; Nadel et al. 2012) that rely on the presence of large numbers of eggs in field populations. 
Observational data from countrywide surveys (Nadel et al. 2010) suggested rainfall caused $T$. peregrinus populations to decrease at certain monitoring sites. The data from this study, however, did not support this hypothesis at the Pretoria site (the only site with reliable rainfall data that could be used for this purpose). Rainfall during spring usually results in a flush of new leaves and shoots that are high in nitrogen, often leading to increases in numbers and feeding of other insects (Wolda 1978; Chilima and Leather 2001). Thaumastocoris peregrinus feeds on mature Eucalyptus leaves and possibly derives no benefit from this increased flush of shoots that usually occurring after first spring rainfalls. The apparent correlation between rainfall and a decrease in populations that has previously been observed (Nadel et al., 2010, authors unpublished) is most likely due to other factors (e.g., such as changes in plant tissue structure or chemistry, pathogen pressure, etc.) (Stiling 1988; Abbott and Dwyer 2007). Population fluctuations after rainfall periods could also be due to changes in other climatic factors, such as humidity and temperature that affect insects and plant-host growth (Specht and Brouwer 1975; Sutcliffe 1977; Jones 2001; Umbanhowar and Hastings 2002; Abbott and Dwyer 2007).

The positive linear relationship between $T$. peregrinus egg development and temperature from $12{ }^{\circ} \mathrm{C}$ until $30{ }^{\circ} \mathrm{C}$ is likely to be an important part in the explanation of the influence of average temperature and population size observed at all monitoring sites. The optimal developmental rate of 3 days with $15 \%$ mortality for $T$. peregrinus eggs was at $30{ }^{\circ} \mathrm{C}$. This rate of egg development was much higher in this study compared to other Thaumastocoridae such as Baclozygum depressum Bergroth, which had a developmental rate of 8 days for eggs at a temperature of $30{ }^{\circ} \mathrm{C}$ (Hill 1988). The rate of egg development in this study at $20{ }^{\circ} \mathrm{C}(7$ days and $10 \%$ mortality) was similar to the developmental rate of T. safordi Noack, Cassis \& Rose eggs that were found to hatch within 8 days when kept at room temperature (Noack and Rose 2007; Noack 2009; Nadel and Noack 2012). However, these results differ from the developmental rates found for T. peregrinus (6 days) and B. depressum (15 days) at room temperature (Hill 1988; Noack and Rose 2007; Noack 2009). Egg developmental rates of insects have been found to decrease with further increases above optimum temperature (Kouskolekas and Decker 1966; Beck 1983; Son and Lewis 2005), as shown with $T$. peregrinus eggs that had $100 \%$ mortality and appeared to dry out at $35^{\circ} \mathrm{C}$ after 5 days.

Mean temperature provides an indication of the thermal environment to which insects are exposed and, conceivably, influence their developmental rate and behaviour (Beck 1983; 
Klueken et al. 2009). One would thus expect to encounter an increasing abundance of $T$. peregrinus with increasing mean temperatures due to the linear relationship with that of mean temperature and egg developmental rates from 12 to $30{ }^{\circ} \mathrm{C}$. This relationship was not found at any of the monitoring sites, suggesting that in addition to mean temperature other environmental factors are likely to also be influencing $T$. peregrinus populations. Two possible other factors suggested by the data analysis were maximum temperature and humidity.

Maximum temperatures might have played a role in fluctuating populations at some of the sites. Observational data from only the Tzaneen and Sabie monitoring sites, however, indicated that increases in mean temperatures above $20{ }^{\circ} \mathrm{C}$ did not necessarily result in increased numbers of $T$. peregrinus. This contradictory result was shown in the data to likely be due to large increases in the maximum $\left(25^{\circ} \mathrm{C}\right.$ to $\left.40{ }^{\circ} \mathrm{C}\right)$ and not that of mean $\left(17^{\circ} \mathrm{C}\right.$ to 22 $\left.{ }^{\circ} \mathrm{C}\right)$ temperatures experienced at these sites. This could result in a decrease in population size during hot summer months when thermal tolerance and thermal limits are met (Crozier 2004; Gaston 2009). For T. peregrinus, a maximum temperature of above $34{ }^{\circ} \mathrm{C}$ may result in egg development ceasing and in turn adult insects reaching their thermal tolerance. Maximum temperatures of over $34{ }^{\circ} \mathrm{C}$ that were consistently ( 23 days over a 122 day period) experienced at the Tzaneen and Sabie monitoring trial sites during the hot summer and early autumn months, sometimes for up to 6 hours a day, could possibly explain the decrease in the number of T. peregrinus individuals encountered during the hot summer months.

High levels of relative humidity have been shown for other insects to positively affect the hatching of eggs and the survival of adults and immature life stages (Byrne et al. 2002; Duyck et al. 2006; Moriyama and Numata 2006; Simmons et al. 2008). However, high humidity at the Zululand, Tzaneen and Sabie monitoring sites were associated with a decrease in T. peregrinus population size. The reason for this is not clear. One possibility is that increases in humidity coupled with increasing temperature may allow for the growth of fungal pathogens on the eggs of T. peregrinus (Mascarin et al. 2012). This phenomenon has previously been observed on T. peregrinus eggs kept at high humidity levels on leaves under laboratory conditions (authors unpublished), but requires further testing. Fungal egg pathogens are not uncommon and have been effectively used to control numerous insect pest populations (Ferron 1978; Samuels et al. 2002). 
Results of this study showed that $T$. peregrinus populations must be separately monitored and in the different regions of South Africa if the data are to be used to accurately predict seasonal abundance peaks. Seasonal synchronicity was quite consistent within sites across the two seasons monitored, potentially allowing for population models to be built that will allow for realistic population predictions and planning in future for specific Eucalyptus spp. in each region. While no clear or consistent link emerged between climate and population fluctuations, more work is needed to understand the strong seasonal patterns in abundance. There are also evidently other factors that affect population fluctuations, as would be expected. Another factor that appears to need specific attention includes the influence of variations in resource quantity, nutritional quality, and volatile organic compounds of the various Eucalyptus spp. (Soliman et al. 2012; Martins and Zarbin 2013) and how this impacts T. peregrinus population dynamics. Such data might be useful to improve our ability to predict future distribution and the severity of outbreaks internationally in regions that are not yet affected by this pest.

\section{Acknowledgements}

Members of the Tree Protection Co-operative Programme (TPCP), the Department of Trade and Industry THRIP programme and the National Research Foundation (NRF) are thanked for financial support. We also thank Botha Maree, Sonia du Buisson, Maurits Perold (Hans Merensky), Rhudolf Müller, Tony Winter (Mondi), Denis Oscroft and Tammy Swain (ICFR), Glen Mitchell and Kholisa Langa (KLF) for their assistance with this trial. We are grateful to Dr. Ilaria Germishuizen of the Institute for Commercial Forestry Research (ICFR) for providing the plantation forestry map (Fig. 1) using the National land-cover database 2000 CSIR/ARC. We also thank the National Zoological Gardens, Pretoria for allowing us to use the Tom Jenkins Eucalyptus plantation for sampling and the South African Weather Service for providing some of the weather data for this study. 


\section{References}

Abbott KC, Dwyer G (2007) Food limitation and insect outbreaks: complex dynamics in plant - herbivore models. J Anim Ecol 76:1004 - 1014.

Addo-Bediako A, Chown SL, Gaston KJ (2000) Thermal tolerance, climatic variability and latitude. Proc R Soc Lond, Ser B: Biol Sci 267:739 - 745.

Beck SD (1983) Insect thermoperiodism. Annu Rev Entomol 28:91 - 108.

Block W, Baust JG, Franks F, Johnston IA, Bale J (1990) Cold tolerance of insects and other arthropods. Philos Trans R Soc Lond B Biol Sci 326 (1237):613 - 633.

Byrne MJ, Currin S, Hill MP (2002) The influence of climate on the establishment and success of the biocontrol agent Gratiana spadicea, released on Solanum sisymbriifolium in South Africa. Biol Control 24:128 - 134

Campbell A, Frazer BD, Gilbert N, Gutierrez AP, Mackauer M (1974) Temperature requirements of some aphids and their parasites. J Appl Ecol 11 (2):431 - 438.

Carpintero DL, Dellapé PM (2006) A new species of Thaumastocoris Kirkaldy from Argentina (Heteroptera: Thaumastocoridae: Thaumastocorinae). Zootaxa 1228:61 - 68.

Chilima CZ, Leather SR (2001) Within-tree and seasonal distribution of the pine woolly aphid Pineus boerneri on Pinus kesiya trees. Agric For Entomol 3 (2):139 - 145.

Crozier LG (2004) Field transplants reveal summer constraints on a butterfly range expansion. Oecologia 141 (1):148 - 157.

Duyck P, David P, Quilici S (2006) Climatic niche partitioning following successive invasions by the fruit flies in La Réunion. J Anim Ecol 75:518 - 526.

Ferron P (1978) Biological control of insect pests by entomogenous fungi. Annu Rev Entomol $23(1): 409$ - 442. 
Fry FEJ (1967) Responses of vertebrate poikilotherms to temperature. In: Rose AH (ed) Thermobiology. Academic Press, London, pp 375 - 409

Gaston KJ (2009) Geographic range limits: achieving synthesis. Proc R Soc Biol Sci Ser B 276 (1661):1395 - 1406.

González A, Calvo MV, Cal V, Hernández V, Doño F, Alves L, Gamenara D, Rossini C, Martínez G (2012) A male aggregation pheromone in the bronze bug, Thaumastocoris peregrinus (Thaumastocoridae). Psyche (New York).

Hill L (1988) The identity and biology of Baclozygum depressum Bergroth (Hemiptera: Thaumastocoridae). J Aust Entomol Soc 27:37 - 42.

Jacobs DH, Neser S (2005) Thaumastocoris australicus Kirkaldy (Heteroptera:

Thaumastocoridae): a new insect arrival in South Africa, damaging to Eucalyptus trees. S Afr J Sci 101:233 - 236.

Jones RE (2001) Mechanisms for locating resources in space and time: Impacts on the abundance of insect herbivores. Austral Ecol 26 (5):518 - 524.

Kay CAR, Whitford WG (1978) Critical thermal limits of desert honey ants: possible ecological implications. Physiol Zool 51 (2):206 - 213.

Klok CJ, Chown SL (1997) Critical thermal limits, temperature tolerance and water balance of a sub-Antarctic caterpillar, Pringleophaga marioni (Lepidoptera: Tineidae). J Insect Physiol 43 (7):685 - 694.

Klueken AM, Hau B, Ulber B, Poehling HM (2009) Forecasting migration of cereal aphids (Hemiptera: Aphididae) in autumn and spring. J Appl Entomol 133 (5):328 - 344.

Kouskolekas CA, Decker GC (1966) The effect of temperature on the rate of development of the potato leafhopper, Empoasca fabae (Homoptera: Cicadellidae). Ann Entomol Soc Am 59:292 - 298. 
Laudonia S, Sasso R (2012) The bronze bug Thaumastocoris peregrinus: a new insect recorded in Italy, damaging to Eucalyptus trees. Bull Insectol 65 (1):89 - 93.

Liebhold AM, Haynes KL, Bjørnstad ON (2012) Spatial Synchrony of Insect Outbreaks. In: Barbosa LR, Letourneau DK, Agrawal AA (eds) Insect Outbreaks Revisited. First edn. Wiley - Blackwell, UK, pp 113 - 125

Lin N, Huber JT, La Salle J (2007) The Australian genera of Mymaridae (Hymenoptera: Chalcidoidea). Zootaxa 1596:3 - 111.

Martínez G, Bianchi M (2010) First record in Uruguay of the bronze bug, Thaumastocoris peregrinus Carpintero and Dellappé, 2006 (Heteroptera: Thaumastocoridae). Agrociencia (Montevideo) 14 (1):15 - 18.

Martínez G, González A, Simeto S, Balmelli G (2010) Monitoring the bronze bug, Thaumastocoris peregrinus (Heteroptera: Thaumastocoridae): effect of trap placement. Int Forest Rev 12 (5):360.

Martins CBC, Zarbin PHG (2013) Volatile Organic Compounds of Conspecific-Damaged Eucalyptus benthamii Influence Responses of Mated Females of Thaumastocoris peregrinus. J Chem Ecol 39 (5):602 - 611.

Mascarin GM, Duarte VdS, Brandão MM, Delalibera Jr Í (2012) Natural occurrence of Zoophthora radicans (Entomophthorales: Entomophthoraceae) on Thaumastocoris peregrinus (Heteroptera: Thaumastocoridae), an invasive pest recently found in Brazil. J Invertebr Pathol 110 (3):401 - 404.

Maywald GF, Kriticos DJ, Sutherst RW, Bottomley W (2007) DYMEX 3.0. Hearne Scientific Publishing, Melbourne

Mitchell JD, Hewitt PH, van der Linde TCDK (1993) Critical thermal limits and temperature tolerance in harvester termite Hodotermes mossambicus (Hagen). J Insect Physiol 39 (6):523 - 528 . 
Moran P (1953) The statistical analysis of the Canadian Lynx cycle. Aust J Zool 1 (3):291298.

Moriyama M, Numata H (2006) Induction of egg hatching by high humidity in the cicada Cryptotympana facialis J Insect Physiol 52:1219 - 1225.

Nadel RL, Noack AE (2012) Current understanding of Thaumastocoris peregrinus in a quest for its management and control. Int J Pest Manag 58 (03):257 - 266.

Nadel RL, Slippers B, Scholes MC, Lawson SA, Noack AE, Wilcken CF, Bouvet JP, Wingfield MJ (2010) DNA bar-coding reveals source and patterns of Thaumastocoris peregrinus invasions in South Africa and South America. Biol Invasions 12 (5):1067 1077.

Nadel RL, Wingfield MJ, Scholes MC, Lawson SA, Noack AE, Neser S, Slippers B (2012) Mitochondrial DNA diversity of Cleruchoides noackae (Hymenoptera: Mymaridae): a potential biological control agent for Thaumastocoris peregrinus (Hemiptera: Thaumastocoridae). BioControl 57 (3):397 - 404.

Noack A, Kaapro J, Bartimote - Aufflick K, Mansfield S, Rose HA (2009) Efficacy of Imidacloprid in the control of Thaumastocoris peregrinus on Eucalyptus scoparia in Sydney, Australia. Arbor Urban For 35 (4):192 - 196.

Noack AE (2009) The taxonomic revision of the genus Thaumastocoris and the biology and chemical control of the eucalypt pest Thaumastocoris peregrinus (Heteroptera: Thaumastocoridae). PhD Thesis, The University of Sydney, Sydney

Noack AE, Cassis G, Rose HA (2011) Systematic revision of Thaumastocoris Kirkaldy (Hemiptera: Heteroptera: Thaumastocoridae). Zootaxa 3121:1 - 60.

Noack AE, Coviella CE (2006) Thaumastocoris australicus Kirkaldy (Hemiptera: Thaumastocoridae): First record of this invasive pest of Eucalyptus in the Americas. Gen Appl Entomol 35:13 - 15. 
Noack AE, Rose HA (2007) Life- history of Thaumastocoris peregrinus and Thaumastocoris $s p$. in the laboratory with some observations on behaviour. Gen Appl Entomol 36:27 33.

Oumar Z, Mutanga O (2013) Predicting water stress induced by Thaumastocoris peregrinus infestations in plantation forests using field spectroscopy and neural networks. Journal of Spatial Science: 1 - 12 .

R Core Team (2012) R: A Language and environment for statistical computing. R Foundation for Statistical Computing, Vienna, Austria

Samuels RI, Coracini DLA, Martins dos Santos CA, Gava CAT (2002) Infection of Blissus antillus (Hemiptera: Lygaeidae) eggs by the entomopathogenic fungi Metarhizium anisopliae and Beauveria bassiana. Biol Control 23 (3):269 - 273.

Simmons AN, Legaspi JC, Legaspi BC (2008) Responses of Delphastus catalinae (Coleoptera: Coccinellidae), a predator of whiteflies (Hemiptera: Aleyrodidae), to relative humidity: oviposition, hatch, and immature survival. Ann Entomol Soc Am 101 (2):378 - 383 .

Soliman E, Wilcken C, Pereira J, Dias T, Zaché B, Dal Pogetto M, Barbosa L (2012) Biology of Thaumastocoris peregrinus in different eucalyptus species and hybrids. Phytoparasitica 40 (3):223 - 230.

Son Y, Lewis EE (2005) Modelling temperature-dependent development and survival of Otiorhynchus sulcatus (Coleoptera: Curculionidae). Agric For Entomol 7:201 - 209.

Sopow S, George S, Ward N (2012) Bronze Bug, Thaumastocoris peregrinus: a new Eucalyptus pest in New Zealand. Surveillance 39 (2):43 - 46.

Specht RL, Brouwer YM (1975) Seasonal growth of Eucalyptus spp. in the Brisbane area of Queensland (with notes on shoot growth and litter fall in other areas of Australia). Aust J Bot 23:459 - 474 . 
Stiling P (1988) Density - dependent processes and key factors in insect populations. J Anim Ecol 57 (2):581 - 593.

Sutcliffe J (1977) Plants and Temperature. Edward Arnold Publishers Ltd., London

Umbanhowar J, Hastings A (2002) The impact of resource limitation and the phenology of parasitoid attack on the duration of insect herbivore outbreaks. Theor Popul Biol 62:259 $-269$.

Wilcken CF, Soliman EP, de Sá LAN, Barbosa LR, Dias TKR, Ferreira-Filho PJ (2010) Bronze Bug Thaumastocoris peregrinus Carpintero and Dellapé (Hemiptera: Thaumastocoridae) on Eucalyptus in Brazil and its distribution. J Plant Prot Res 50 (2):201 - 205.

Wolda H (1978) Seasonal fluctuations in rainfall, food and abundance of tropical insects. J Anim Ecol 47 (2):369 - 381. 